\title{
A gyász új perspektívái
}

\author{
Csikós Ágnes dr. ${ }^{1}$ - Menyhért Mónika² \\ Radványi Ildikó dr. ${ }^{1}$ - Busa Csilla ${ }^{1}$
}

${ }^{1}$ Pécsi Tudományegyetem, Általános Orvostudományi Kar, Családorvostani Intézet, Hospice-Palliatív Tanszék, Pécs

${ }^{2}$ Pécsi Tudományegyetem, Klinikai Központ, Palliatív Mobil Team, Pécs

\begin{abstract}
A gyász az élet természetes része, és mindig egyedi formát ölt. A kutatók mégis megpróbáltak és megpróbálnak különböző teóriákat kidolgozni, hogy értelmezzék, magyarázzák és emberközelivé tegyék ezt a különleges jelenséget. A szerzők célja napjaink gyászelméleti irodalmának áttekintése és a külföldön már bemutatásra került gyászelméletek megismertetése a hazai szakemberekkel. A XX. század első fele óta a gyászelméletek jelentős változáson mentek keresztül. Az újabb gyászelméletek több ponton is szakítanak a korábbi elméletek elgondolásaival. A gyász szakaszokra osztása helyett a rugalmas, megküzdésorientált kettős folyamatmodell, a jelentésalkotási folyamatot középpontba helyező jelentéskonstrukció-elmélet, valamint a veszteséget követő, fejlődésre fokuszáló modellek a meghatározóak. A szerzők fontosnak tartják, hogy a klinikumban tevékenykedő kollégák megismerjék a legújabb gyászelméleteket, hiszen munkájuk során gyakran találkoznak veszteséggel és veszteséget megélő emberekkel. A bemutatott modellek hozzájárulnak a hatékony munkavégzéshez, a gyászfolyamat jobb megértéséhez és a gyászolók megfelelőbb támogatásához. Orv. Hetil., 2015, 156(39), 1569-1576.
\end{abstract}

Kulcsszavak: palliatív ellátás, gyász, gyászelmélet, gyásztámogatás

\section{New perspectives of mourning}

Grief is a natural part of life and it is always individual. Researchers have tried and still try to develop different theories to interpret, explain, and approach this particular phenomenon. The aim of the authors was to review the theoretical literature of mourning and to present new bereavement theories for domestic professionals. From the first half of the 20 th century until presently mourning theories have undergone significant changes. Today the determinant models includes the flexible, coping-oriented dual process model, meaning reconstruction model which focuses on the meaning making, and the model which focuses on the development after the loss. The authors conclude that experts, who work in the clinical area should know the prevailing theories of grief, because they encounter often with loss at work. The presented models may contribute to more efficient work, to better understanding of the mourning process and to a better support of families.

Keywords: palliative care, bereavement, grief theory, bereavement support

Csikós, Á., Menybért, M., Radványi, I., Busa, Cs. [New perspectives of mourning]. Orv. Hetil., 2015, 156(39), 1569-1576.

(Beérkezett: 2015. június 19.; elfogadva: 2015. július 16.)

A veszteség és a gyász az emberi élet alapvető tapasztalata, elkerülhetetlen és univerzális. A klinikumban tevékenykedő szakemberek munkájuk során nap mint nap találkoznak veszteséggel és gyászoló családokkal. Fokozottan igaz ez a palliatív ellátásban dolgozókra. A palliatív ellátás, ahogy a definícióból is kiderül, a testi tünetek enyhítése mellett, kiemelt fontosságúnak tartja a lelki terhek mérséklését [1]. A lelki terhek csökkentése magában foglalja a gyásztámogatást is. Ezt a feladatot akkor tudják a szakemberek a leghatékonyabban megvalósítani, ha tisztában vannak azzal, mi játszódhat le a hozzátartozóban a veszteséget megelőzően, a bekövetkezésekor és utána. Ebben nagy segítségükre vannak a gyászelméletek, amelyek megpróbálják értelmezni, magyarázni és emberközelivé tenni ezt a különleges jelenséget.

A gyászról való gondolkodás és elmélkedés jelentős változásokon ment keresztül a kezdetektől napjainkig [2]. 
A korai gyászelméletek, mint Freud, Lindemann és Bowlby elmélete, voltak azok, amelyek lerakták az alapjait és elsőként foglalkoztak a gyász témájával [3]. Hamarosan megjelentek és népszerűvé váltak azok a teóriák, amelyek szakaszokra bontották a gyász folyamatát. A legelterjedtebbek között van Kübler-Ross 5 szakasza [4], és a Pilling János által megalkotott szakaszok: anticipációs gyász, sokk, kontrollált szakasz, depresszió, átdolgozás, adaptáció [5].

Napjainkban a gyász szakaszokra osztása helyett elmozdulás történt a modellek irányába [6]. Arra törekszenek, hogy alkalmazkodjanak a gyászélmény sokszínüségéhez. Az újabb modellek és a hagyományos elméletek közötti fó különbségeket az 1. táblázat foglalja össze [7]. Mindegyik más lencsén keresztül vizsgálódik, és mindegyik másra helyezi a hangsúlyt: a bemutatásra kerülő három gyászelmélet is három különböző perspektívából mutatja be a gyász jelenségét. Stroebe és Schut kettősfolyamat-elmélete átfogó, rugalmas és megküzdésorientált [8], Neimeyer a jelentésalkotási folyamatra helyezi a hangsúlyt [9], míg Hogan [10], Tedeschi és Calhoun [11] a veszteséget követő növekedésre, fejlődésre fokuszálnak.

\section{A gyász kettősfolyamat-modellje}

Stroebe és Schut nevéhez kötődik a kettősfolyamat-elmélet. A szerzők a korábbi szakasz- és feladatelméletek erôsségeit és korlátait figyelembe véve fejlesztették ki modelljüket. Nagyban építenek a kognitív stressz elméletére, és a gyásszal történő megküzdést egy dinamikus folyamatnak írják le [12]. Gyászfeldolgozó rendszerüket az 1. ábra szemlélteti [12], amelynek három fontos eleme van: a veszteségorientáció, a helyreállítás-orientáció

1. táblázat | A hagyományos elméletekkel szemben az újabb gyászelméletek jellemzői

1. Szkeptikusak a gyász kiszámítható érzelmi pályájával kapcsolatban, amely az egyensúly hiányától a helyreállásig tartana.

2. Elmozdulnak attól a feltételezéstől, hogy a sikeres gyászfeldolgozás feltétele az, ha elengedjük az elhunytat. Helyette fontosnak tartják a folyamatos szimbolikus kötelék fenntartását

3. A hagyományos, érzelmekre és tünetekre való fokuszálás mellett figyelmet fordítanak a gyásszal együtt járó jelentésalkotási folyamatokra is.

4. Nagyobb figyelmet szentelnek az egyén identitásának. A gyászfolyamat során gyakran szükséges a gyászoló önmaga újbóli meghatározása.

5. Nagyobb hangsúlyt fektetnek a spiritualitásra és a poszttraumás növekedésre, amelyek segítenek integrálni a veszteség tanulságait.

6. Szélesítik a figyelem fókuszát: nemcsak a gyászoló egyéni tapasztalataira figyelnek, hanem a család és a tágabb kulturális csoport hatásaira is.

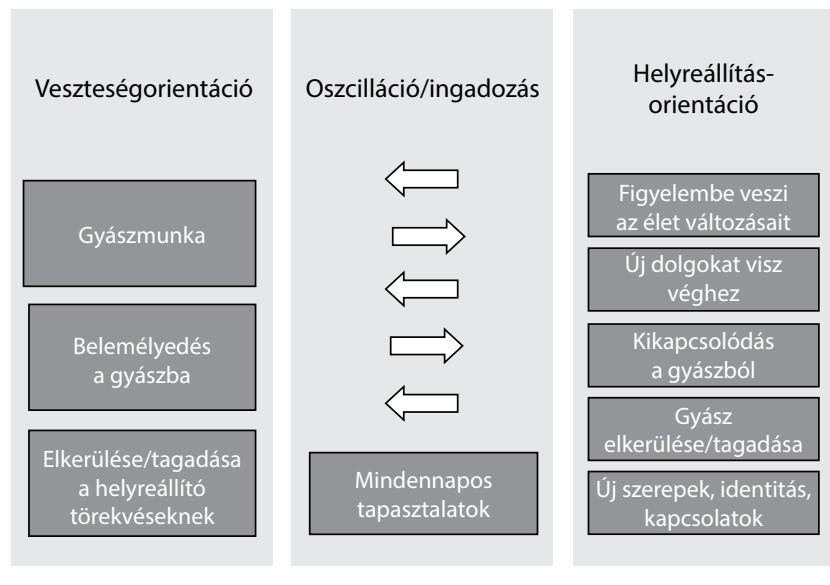

1. ábra

| A gyász kettősfolyamat-modellje

és az oszcilláció [8]. A veszteség- és helyreállítás-orientáció a stresszorok különböző csoportjával vannak kapcsolatban. Létezik az úgynevezett elsődleges stresszor, ami maga a veszteség, a másodlagos stresszor pedig a veszteség kiváltotta egyéb nehézségek, amelyekkel a gyászolónak szembe kell néznie. Veszteségorientáció során a gyászoló az elhunytról, kettejük kapcsolatáról, életükról, halálának eseményeiról elmélkedik. Vagyis minden olyan magatartás, viselkedés és érzelem idetartozik, ami a veszteséggel kapcsolatos: a kellemes visszaemlékezéstől a fájdalmas és kétségbeesett vágyakozásig [8]. A helyreállításorientáció a veszteség másodlagos következményeire fokuszál: új feladatok elsajátítása (például: pénzügyek kezelése), új identitás kialakítása (például: özvegy), az elhunyt nélküli élet megszervezése. Ezen feladatokkal kapcsolatos érzelmek is széles skálán mozoghatnak a megkönnyebbüléstől és büszkeségtől (hogy meg tudtam csinálni) egészen a szorongásig és félelemig (mert esetleg nem sikerült valami). Mindkét orientáció tehát a megküzdési folyamat része, de részvételi arányuk az idő előrehaladtával változik: ahogy halad elöre a folyamat, úgy kap nagyobb szerepet a helyreállítás-orientáció [12]. A modell központi eleme az oszcilláció. Ez felelős a két orientáció váltakozásáért: szabályozza a gyásszal kapcsolatos különböző stresszorokkal való konfrontációt vagy azok elkerülését. Ez a dinamikus reguláció egy oda-viszsza zajló folyamat: néha a gyászoló konfrontálódik a veszteséggel, máskor pedig elkerüli a fájó emlékeket, másra koncentrál [8]. Az elmélet szerint az optimális megküzdéshez és helyreállításhoz szükség van a váltakozásokra. Így őrizhető meg a mentális és fizikai egészség, hiszen ebben az esetben nem állandó vagy extrém elfojtásról van szó, hanem arról, hogy a gyászolónak lehetősége van elterelni a gondolatait vagy új dolgokra figyelnie, amikor túl fájdalmas lenne szembesülni a gyásszal [8].

Ha az oszcilláció zavart szenved, akkor beszélhetünk komplikált gyászról. Ilyenkor vagy a veszteségorientáció, vagy a helyreállítás-orientáció kerül túlsúlyba, a másik pedig hiányt szenved. Ekkor a gyászban való extrém elmélyülésról vagy épp ellenkezőleg, annak extrém tagadá- 
sáról beszélhetünk. Traumatikus veszteség esetén előfordulhat, hogy a veszteségorientációt az oszcilláció mechanizmusa kevésbé tudja kontrollálni és extrém, erőszakos módon törnek elő a gyásszal kapcsolatos gondolatok és érzések, például rémálmok formájában $[8,13]$. A szakember feladata, hogy támogassa az oszcilláció folyamatát, vagyis a megfelelő egyensúlyt a veszteség- és a helyreállítás-orientáció között.

\section{A gyász jelentéskonstrukció-elmélete}

Neimeyer a konstruktivista szemlélet tükrében alkotja meg gyászteóriáját [14]. A szociális konstruktivista elmélet amellett érvel, hogy a gyász nem kizárólagosan intrapszichés, belső pszichológiai folyamat, hanem egy többszintü jelenség: biológiai, intrapszichés, interperszonális, társadalmi és kulturális [15]. Interperszonális, mivel a család, a társak, sőt tágabb értelemben a társadalom és a kultúra is hatással van a gyász központi folyamatára, a jelentésalkotásra. A gyász egy interpretatív és kommunikatív tevékenység: a társas interakciók során az elhunyt életéről, haláláról és a gyászolóval való kapcsolatáról folytatott beszélgetések és megalkotott történetek hozzájárulnak a haláleset jelentésének megtalálásához, valamint a gyászoló új szelfnarratívájának felépítéséhez. $\mathrm{Az}$ elhunyt életével kapcsolatos történetek megosztása, az elvesztett álmok nyilvánosságra hozása segít a gyászolónak felszínre hozni az érzéseit, valamint helyreállítani a rendet és a jelentést a világban, amit korábban a veszteség tönkretett. Tehát a jelentéseket a gyászolók az értelmező és kommunikációs tevékenységeken keresztül találják meg [15].

A gyász és a jelentésalkotás szorosan egymásba fonódó folyamat [15]. Neimeyer abból indul ki, hogy az ember megrögzött jelentésalkotó, illetve, hogy a narratívák szövése ad struktúrát az életünknek [14].

Az emberek alapvetóen motiváltak arra, hogy kialakítsanak és fenntartsanak egy értelmes szelfnarratívát. Ez a szelfnarratíva egy átfogó kognitív, affektív és viselkedési struktúra, amelyet a mindennapi élet mikronarratívái szerveznek makronarratívákká, és amely megszilárdítja a saját magunkról kialakított képünket és elirányít bennünket a szociális világban. Az egyén identitása alapvetően a narratívák eredménye [16], vagyis önmagunk érzése a történeteken keresztül teremtődik meg. Idetartoznak azok a történetek, amelyeket megosztunk másokkal az életünkről, illetve azok, amelyeket mások mesélnek rólunk [15]. A szelfnarratívák gerincét az alapvető hiedelmeink és feltételezéseink adják a világról. Ezek a hiedelmek és feltételezések segítenek interpretálni a tapasztalatokat és koordinálják az emberi kapcsolatainkat. A legalapvetőbb ilyen hiedelmeink, hogy az emberek megérdemlik a történetek pozitív kimenetelét, hogy jelentős kontrollt tudnak gyakorolni az életük felett és hogy a világ általában jóindulatú [16].

A veszteség, amit átélünk, lehet konzisztens vagy inkonzisztens a gyászoló veszteség előtti jelentésstruktúrá- jával. Azok a veszteségek lesznek konzisztensek, amelyekre a gyászoló magyarázatot tud adni, vagy amelyekhez képes jelentést, értelmet hozzárendelni a jelentés struktúrájából. Ezek az események is distresszt váltanak ki, de kevésbé intenzívet és bomlasztót, mint az inkonzisztens veszteségek. Ha ez a folyamat játszódik le, akkor megerősítődnek a gyászoló addigi jelentésstruktúrái: „Úgy múködik a világ, ahogy elképzeltem.” Ha a haláleset inkonzisztens a gyászoló jelentésstruktúrájával, akkor a distressz mellett disszonanciát is megél: rájön, hogy a korábban igaznak és értelmesnek vélt feltételezései és konstrukciói a világról, illetve annak múködéséről nem igazak, nem értelmesek és nem is hasznosak [16]. Az életünk koherenciájának megbomlásakor tudatosan kell megtalálnunk a veszteség tapasztalatának jelentését, míg korábban a hiedelmeink és feltételezéseink jórészt észrevétlenül múködtek [17]. Ez magában foglalja az egyszerû, mindennapi rutinok felülvizsgálatát, például: reggeli közös kávék, amelyek mikronarratíváknak tekinthetők. Ezáltal sérülhet a többi szint is: a makronarratívák szintje és az identitás, a szelfnarratívák szintje is [17].

Neimeyer szerint a veszteség hatására beindul a jelentésalkotási folyamat, a jelentéskonstrukció, amely 3 részból áll, és amit a 2. ábra szemléltet [9]:

1. Jelentés/értelem megtalálása: A gyászoló felülvizsgálja, újraalkotja és megújítja a világ múködésével kapcsolatos jelentéskonstrukcióit. A gyászoló új, a veszteség utáni jelentésstruktúrákat alkot, amiken keresztül más módon látja majd a világot. Ha ezen konstrukciók segítségével magyarázatot talál a halálesetre, megtalálja annak értelmét és jelentését, akkor csökken a gyászoló distresszszintje. Ha ez az új struktúra nem segít a tapasztalatoknak jelentést adni és nem csökken a gyászoló distressz-szintje, akkor újra elindul a folyamat, mert a jelentésstruktúrák nem bizonyultak megfelelőnek. A distressz tehát fontos szerepet játszik a folyamatban: beindíthatja vagy leállíthatja a jelentés keresését [9].

2. Elöny/haszon megtalálása: Megtalálni a veszteségben a "hasznot”, szignifikáns szerepet játszik az eseményhez való alkalmazkodásban. Segít a világ helyreállításában és a dolgok elrendezésében. Ez az előny sokféle lehet: személyes, spirituális, filozófiai stb. Megtalálni egy veszteség hasznát/előnyét, nehéz feladat, éppen ezért nem biztos, hogy a gyászoló röviddel a veszteség után képes erre, lehet, hogy csak hónapokkal vagy évekkel később lesz erre kész [9].

3. Identitás változása: Párhuzamosan azzal, hogy újjáépíti a gyászoló a világ múködésével kapcsolatos jelentéseit, rekonstruálja saját magát is. Módosítja, megváltoztatja az önmagával kapcsolatos érzéseit, felfogásait. Ez a folyamat fájdalommal és gyötrelemmel járhat, de ezzel párhuzamosan nagyon sok pozitív változást is megélhet a gyászoló [9]. Ezt nevezi a szakirodalom személyes vagy poszttraumás növekedésnek [18].

Neimeyer elméletében tehát a gyász egy egyedi, aktív jelentéskonstrukciós folyamat [7], amelynek központi eleme a veszteség jelentésének a megtalálása [14]. Az 




2. ábra

| A gyász jelentéskonstrukció-elmélete

egyediség a következőket jelenti: nincs két ember, akik egyformán reagálnának ugyanarra a veszteségre [7]. Fontosnak tartja továbbá, hogy a gyász egy aktív folyamat: a gyászoló döntések sorozatát kénytelen meghozni ebben az időszakban, tehát képes aktívan alakítani a folyamatot [7].

Számos tanulmány bizonyítja, hogy a gyász során a hozzátartozók keresik a veszteségük jelentését, értelmét $[19,20]$. Sôt a jelentésalkotás a gyászfolyamat során adaptív. A képesség, hogy a gyászoló fel tud építeni egy történetet, amely érthetőbbé, jelentéstelivé teszi a veszteséget, pozitívan hat a gyász lefolyására [15]. Ezt is számos vizsgálat támasztja alá: azok a gyászolók, akik képesek erre, kisebb intenzitású és alacsonyabb distresszel járó gyásztüneteket mutatnak, illetve kevesebb komplikált gyásztünetrôl számolnak be [21].

Abban az esetben, amikor a veszteség túl korai, hirtelen vagy erőszakos, túl nagy támadás éri az egyén hiedelmeit és világképét, ezért a veszteség jelentésének a megtalálása elhúzódhat. Ha viszont a gyászoló sikeresen megtalálja a jelentést, jobban adaptálódik és boldogul [16].
Ebben az elméleti keretben a komplikált gyászt úgy lehet értelmezni, mint amikor az egyén képtelen arra, hogy rekonstruálja a személyes valóságát. Ennek következtében az én múködése bizonytalan és a kapcsolatai is sérülékenyek lesznek [14]. Konstruktivista nézőpontból a gyászterapeuta feladata, hogy segítsen a kliensnek feltárni és tudatosítani, hogy milyen hiedelmei vannak a világról, az életről és hogy ezek hogyan változtak a veszteséget követően. A szakember másik fontos feladata az új jelentések kialakításának támogatása [9] és a koherens szelfnarratíva kiépítése, amelybe már integrálva van a veszteség is [16].

\section{A gyász növekedéselméletei}

Régóta ismert az az elképzelés, hogy az ember életében bekövetkező traumatikus események, mint például egy szeretett hozzátartozó elvesztése, növekedéshez, fejlődéshez is vezethet [10]. A hagyományos gyászelméletek azonban a gyász negatív következményeire fokuszálnak, meg sem említik a növekedés, fejlődés lehetőségét [18]. Azt feltételezik, hogy a gyász intenzitása az idő előreha- 


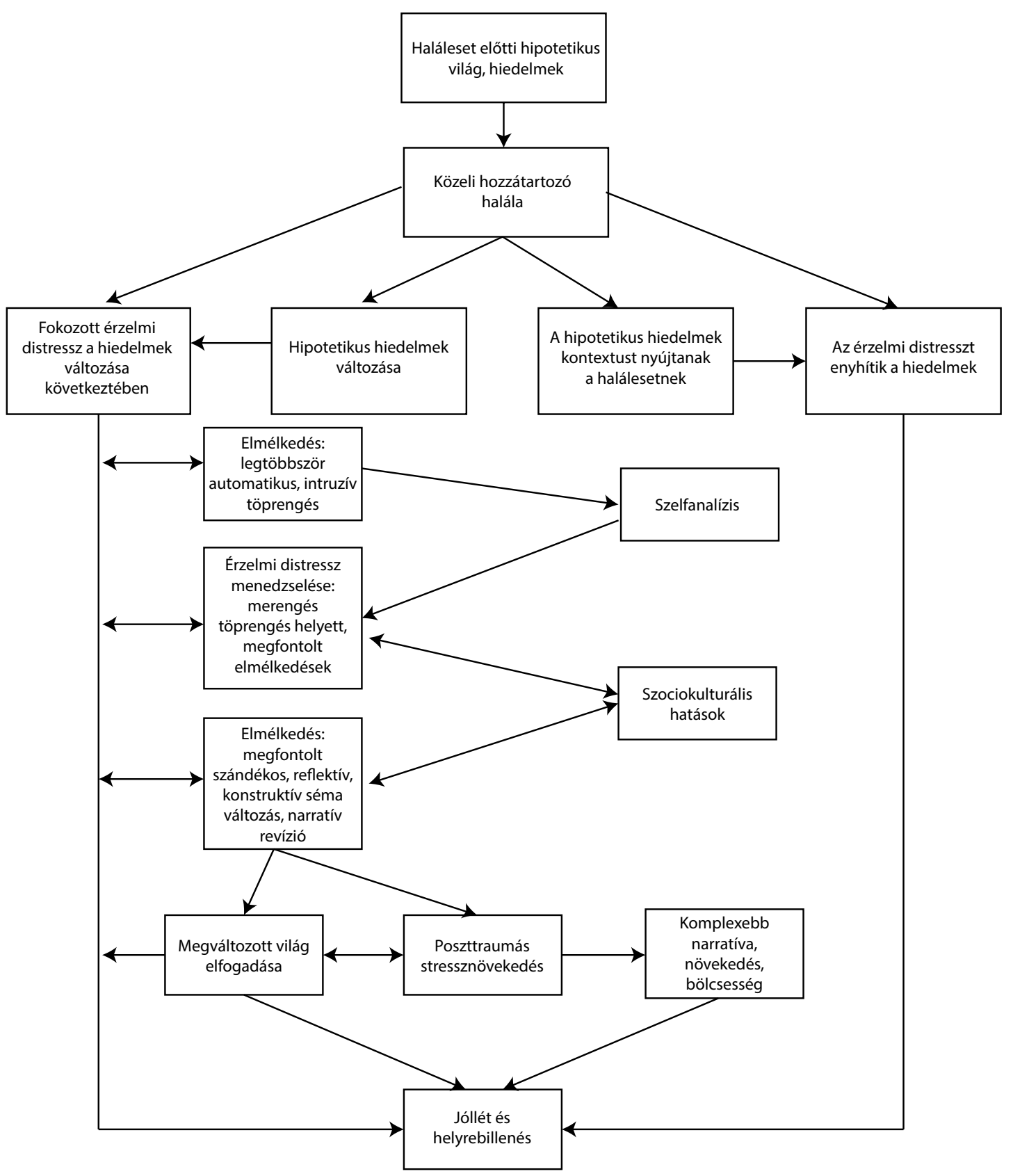

3. ábra

| Poszttraumás növekedés

ladtával csökken, és valamilyen megoldással végződik. A gyászfolyamat végére a gyászoló visszatér a „normális kerékvágásba”, a veszteség előtti, eredeti pszichológiai múködési szintre [10]. Ezzel szemben az újabb gyászelméletek azt vallják, hogy egy szeretett személy elvesztése minőségi változásokat eredményezhet a gyászoló életében és pszichológiái múködésében. Vagyis a gyász eredményeként mind a felnőttek, mind a gyerekek minőségileg és mennyiségileg különböznek a veszteség előtti pszichológiai állapotukhoz képest [3]. A kutatók ezt a jelenséget különböző nevekkel illették: megtanult lecke, pozitív pszichológiai változás, pozitív következmény, kritikus életesemények pozitív aspektusai, növekedés, személyes növekedés, poszttraumás növekedés [10].

Hogan nevéhez kötődik a gyász személyesnövekedésmodellje. A modell legfontosabb fogalmai: kétségbeesés, leválás, betolakodás, társas támogatás, személyes növekedés [10]. A kétségbeesés magában foglalja az együttesen elképzelt jövő reményének a megsemmisülése miatt érzett fájdalmat, a hiány érzésének a gyötrelmét, és a vágyakozást az elhunyt iránt, amelyhez gyakran a tehetetlenség és reménytelenség érzése társul [10]. A kétségbeeséssel párhuzamosan a gyászoló visszavonul, elkülönül másoktól és mély önvizsgálatot tart. Ez a leválás 
folyamata. A gyászoló önmagával és másokkal kapcsolatban is bizalmát veszti, attól tart, hogy elveszíti a kontrollt az élete felett: összezavarodott, nem érzi azt, hogy tudná, ki is ő valójában. Mind inter-, mind intraperszonálisan is válságot él meg. Hívatlan, tolakodó gondolatok, érzések és képek okoznak számára szenvedést, amelyeket megpróbál elkerülni. A gyászfolyamat bizonyos pontján fordulóponthoz érkezik a gyászoló, amikor is igénybe vesz vagy felajánlják számára a társas támogatás lehetőségét. Ezek olyan beszélgetéseket jelentenek, amelyek során a gyászoló őszintén és nyíltan kifejezheti a gondolait, érzéseit, fájdalmát, a szakember vagy a társ pedig aktívan és ítélkezés nélkül meghallgatja. Fontos, hogy a beszélgetések során a gyászoló szenvedésének, átalakulásának és növekedésének minden története el és ki legyen mondva. Továbbá a gyászoló támogatást kap abban, hogy a személyes növekedés irányába mozduljon el a jelentős veszteség után: értelmet és célt találjon, újjáépítse az identitását, a kapcsolatait és a világnézetét, amelyből már hiányzik az elhunyt. A folyamat akkor ér célt, amikor a gyászolónak több jó, mint rossz napja van, amikor el tudja engedni az intenzív gyászt, amikor legyőzi a reménytelenséget, és a jövővel kapcsolatban optimista szemléletûvé válik. A változások eredményeképpen megbocsátóbb, könyörületesebb, toleránsabb lesz másokkal és saját magával is [3]. A személyes növekedés két útját írja le a modell: az egyik, amikor a gyász hatására közvetlenül bekövetkezik a személyes fejlődés, a másik pedig, amikor a gyászoló a növekedés előtt megtapasztalja az intruzív gondolatokat és érzéseket az elhunytról és a halál körülményeiről, amelyeket megpróbál elkerülni, és az elkerülés, valamint az intruzivitás között oszcillál [10].

Tedeschi és Calhoun a poszttraumás növekedés kifejezést használja a gyászfolyamatot követő fejlődésre, és a következőképpen definiálják azt: „Komoly kihívást jelentô életkrízisekkel való küzdelem eredményeként bekövetkező pozitív változás tapasztalata" [11]. Egy olyan változás, amely több annál, mint hogy a gyászoló ellenállóbbá és kevésbé sérülékenyebbé válik intenzív stresszkörülmények között [22]. Egy minőségi változást jelent a múködésben, amely magában foglalja a trauma előtti alkalmazkodási szint meghaladását [11].

A modell kulcselemei azok a világ múködésével kapcsolatos hiedelmek, amelyekkel az emberek általában rendelkeznek. A hiedelmek segítenek eligazodni a világban, megmutatják, hogyan múködik a környezetünk, hogyan bontakoznak ki az egyes események, és hogyan lehet ezeket az eseményeket befolyásolni. Tervezhetővé, kiszámíthatóvá és értelmessé teszik számunkra a világot [23].

A szerzők azt mondják, hogy egy szeretett hozzátartozónk halála nagyfokú érzelmi distresszel és a veszteség élményével jár, függetlenül attól, hogy milyen körülmények között veszítettük el őt. A traumatikus események képesek megváltoztatni vagy összetörni a hiedelmeink világát, ha az adott esemény nem illik bele az elképzelé- seinkbe, hiedelmeinkbe. Ezt alátámasztja az a tapasztalat, hogy bizonyos halálesetek sokkal nagyobb kihívást jelentenek az egyén számára, mint mások. Ebben az esetben a közeli hozzátartozó halálát „természetellenesnek” ítéljük, vagyis nem illik bele a világról alkotott hipotetikus elképzeléseinkbe. Ekkor megváltoznak, összetörnek a hiedelmeink és nagyfokú érzelmi distresszt élünk át.

A modell következő kulcseleme az elmélkedés, amely egy összetett folyamat, ami lehet konstruktív és nem konstruktív, attól függően, hogy támogatja-e a negatív gondolatokat és érzelmeket vagy segít a gyászolónak elmozdulni a problémamegoldás irányába. A szerzők kétféle elmélkedést különböztetnek meg: az intruzív, tolakodó és a megfontolt, szándékos elmélkedést. Az előbbi általában olyan gondolatokat és érzéseket takar, amelyeket nem tud kontrollálni a gyászoló, általában nemkívánatosak, és kapcsolatban állhatnak a poszttraumatikus stressz-szindróma tüneteivel. A megfontolt, szándékos elmélkedés során az egyén próbálja újjáépíteni az összetört világképét és megérteni az eseményeket. A gyászfolyamat során a két elmélkedési típus egymás mellett van jelen, oszcillálnak, de a nem kívánt, tolakodó gondolatok intenzívebbek az első időszakban, és ahogy egyre célorientáltabban, tudatosabban, konstruktívabban gondolkodik, úgy csökken az arányuk. Ha nem sikerül újjáépíteni a hiedelmeket, akkor a tolakodó gondolatok és a distressz marad túlsúlyban [22]. Erre a kognitív rekonstrukcióra a szociokulturális hatások is befolyással vannak: léteznek olyan rítusok, modellek vagy sémák, amelyek megkönnyítik a növekedést és jó irányba terelik a folyamatot, illetve vannak olyanok is, amelyek negatívan hatnak, például jogfosztott gyász esetében [24].

A hiedelmek, a világnézet sikeres újjáépítése és a megváltozott világ elfogadása együtt járhat a növekedéssel, amely magában foglalja a világ és az emberek komplexebb értékelését és megbecsülését. Az egyének felismerik a saját erősségeiket és közelebb érzik magukat másokhoz. Elfogadják, hogy a világ nem mindig „fair” (rossz dolgok történhetnek jó emberekkel is), az események nem mindig kontrollálhatók és a rossz dolgokat nem lehet mindig megelőzni [22]. A növekedés megnyilvánulhat továbbá az élet fokozott értékelésében, az élet prioritásainak módosulásaiban, az egzisztenciális és spirituális élmények gyarapodásában [11]. A pozitív változásokat, a pozitív szelfátalakulásokat általában a következőképpen írják le a gyászolók: türelmesebbek, toleránsabbak, empatikusabbak, függetlenebbek, nagyobb az önbizalmuk, együttérzőbbek, gondoskodóbbak [25], illetve a gyász már jól ismert negatív tüneteit (szorongás, depresszió, érzelmi distressz, különböző szerhasználat) alacsonyabb szinten élik át [18]. Linley és Joseph felmérése szerint a gyászolók 30-70\%-a beszámol az élete minőségi változásáról, átalakulásáról [26]. A növekedés megvalósulását és mértékét befolyásoló tényezőket a 2. táblázat foglalja össze [18, 27, 28, 29]. 
2. táblázat | A poszttraumás növekedést befolyásoló tényezők

1. Életkor: Kell egy bizonyos kognitív érettség ahhoz, hogy bekövetkezzen a poszttraumás növekedés.

2. Nem: Nincsenek egyértelmú eredmények, bár a legutóbbi vizsgálatok szerint a nők nagyobb növekedésről számolnak be, mint a férfiak.

3. Szociális támogatás: A támaszkeresés a gyász időszakában hozzájárulhat a konstruktív információfeldolgozáshoz, amely megváltoztathatja a sémákat és hozzájárulhat a növekedéshez.

4. Vallás: A vallás, a spiritualitás általában, de nem mindig előnyös a poszttraumás növekedés szempontjából.

5. A haláleset óta eltelt idő: Ahogy nő a haláleset óta eltelt idő, kevésbé tapasztalnak fejlődést a gyászolók a növekedés két területén: az élet megbecsülése és a másokhoz való kapcsolódás.

Abban az esetben viszont, amikor a közeli hozzátartozónk halála beleillik a hipotetikus hiedelmeink kontextusába, a hiedelmek nem változnak meg, sőt enyhítik a halálesettel járó distresszt, és rövid időn belül helyrebillen a gyászoló belső harmóniája, pszichés jólléte. Az a haláleset, amelyik nem jár együtt a hiedelmek jelentős újragondolásával, kevésbé eredményez növekedést [22].

Ebben az elméleti keretben a gyászterápia alapja a rekonstrukció: a hiedelmek, a jelentések és az élettörténet újjáépítése. A szakember ezen keresztül tudja támogatni a poszttraumás növekedést és csökkenteni a gyászoló distressz-szintjét. Calhoun és Tedeschi elsősorban gyermeküket gyászoló szülőkkel dolgoztak, és tapasztalataik alapján megfogalmazták a gyásszal foglalkozó szakember 5 legfontosabb jellemzőjét [22]:

1. Tisztelje és alázattal forduljon a gyászoló alapvetó hiedelmei felé!

2. Legyen állhatatos és tartsa szem előtt, hogy a gyász egy hosszú folyamat!

3. Tolerálja a gyászoló különös, néha irreális, máskor homályos és zavaros elképzeléseit, gondolatait!

4. Legyen elég bátor, hogy meghallgassa a gyászolók történeteit!

5. Fogadja el a gyászoló történetének paradoxonjait!

\section{Következtetések}

Napjainkban a gyásszal foglalkozó elméletalkotók a statikusabb leírások helyett egy sokkal dinamikusabb irányba mozdulnak el. Olyan elképzelések irányába, amelyek jobban alkalmazkodnak a gyász egyediségéhez és sokszínûségéhez. De egyetértünk Parkes gondolataival, miszerint a korábbi és a jelenlegi nézópontok is validak, továbbá mindegyiknek megvan a maga haszna [30]. Cikkünkben három gyászelméletet mutattunk be. Fontosnak tartjuk, hogy a klinikumban dolgozó kollégák, kiváltképp a palliatív ellátást végző multidiszciplináris team tagjai megismerjék ezeket a teóriákat.

A fent bemutatott elméletek segítségével a munkánk során hozzá tudunk járulni, hogy
- a családtagok megalkossák a maguk veszteségtörténetét, jelentését és identitását;

- megerősítsük őket abban, hogy teljesen természetes, sőt szükséges, hogy a napjuk egy részében „elfelejtkezzenek” a fájdalmukról és „kikapcsolódjanak”, a másik részében pedig a gyásszal foglalkozzanak;

- a fejlődés, növekedés irányába induljanak el.

Úgy gondoljuk tehát, hogy a modellek hozzájárulnak a hatékony munkavégzéshez, a gyászfolyamat jobb megértéséhez és a gyászolók megfelelőbb támogatásához. Munkánk során tapasztaljuk, hogy a krónikus, progresszív betegséggel küzdőknél a betegség teljes folyamatában ott lebeg a szeretett személy elvesztésének a lehetősége [31]. Éppen ezért kiemelt fontosságú a hozzátartozók gyászfolyamatának támogatása már a beteg halála előtt és után is: minden elhangzott szó, minden megütött hangnem hozzájárul a gyászoló tapasztalataihoz és a gyászfolyamat sikeres lefolyásához. A hozzátartozónak szüksége van arra, hogy megértse a halál folyamatát és beszéljen az érzéseiról, az aggodalmairól. A haláleset bekövetkezte előtt pedig közvetetten, a hozzátartozó támogatásával tudjuk segíteni a beteget magát is. Ha a hozzátartozó nyugodtabb, kiegyensúlyozottabb és tisztában van azzal, hogy mi várható, a beteg is biztonságosabban érzi magát és alacsonyabb distresszt él meg.

Anyagi támogatás: A közlemény megírása, illetve a kapcsolódó kutatómunka anyagi támogatásban nem részesült.

Szerzői munkamegosztás: Cs. Á.: A hipotézis kidolgozása, a vizsgálat lefolytatása. M. M.: A vizsgálat lefolytatása, a kézirat megszövegezése. R. I., B. Cs.: A kézirat megszövegezése. A kézirat végleges változatát valamennyi szerző elolvasta és jóváhagyta.

Érdekeltségek: A szerzőknek nincsenek érdekeltségeik.

\section{Irodalom}

[1] Radbruch, L., Payne S.: White paper on standards and norms for hospice and palliative care in Europe - part 1. Recommendations from the European Association for Palliative Case. [Fehér Könyv az európai hospice és palliatív ellátás standardjairól és normáiról. Az Európai Palliatív Szövetség ajánlásai - 1. rész.] KHARÓN Thanatológiai Szemle, 2010, 14(3), 1-28. http://www.google. $\mathrm{hu} / \mathrm{url}$ ? $\mathrm{sa}=\mathrm{t} \& \mathrm{rct}=\mathrm{j} \& \mathrm{q}=\&$ esrc $=\mathrm{s} \&$ source $=$ web \& $\mathrm{cd}=2 \& \mathrm{kved}=0 \mathrm{CC}$ cQFjAB\&url=http $\% 3 \mathrm{~A} \% 2 \mathrm{~F} \% 2$ Fwww.wesley.hu\%2Fsites $\% 2 \mathrm{Fdefa}$ ult\%2Ffiles\%2Ffajlok\%2Fcikk_hospice_feherkonyv.pdf\&ei=gpD QVMTnK4TwUsiJhJAL\&usg=AFQjCNGtcUNzR2sSfuC2cBu n9IbsAfWVSQ\&sig2=p08GfFrYatIGM4ki6zl rbA\&bvm=bv.85 076809,d.d24 [Hungarian]

[2] Sarungi, E., Varga, H.: Mourning and health. In: Csabai, M., Pintér, J. N. (eds.): Psychology in healing. [Gyász és egészség. In: Csabai, M., Pintér, J. N. (szerk.): Pszichológia a gyógyításban.] Oriold és Társai Kiadó, Budapest, 2013. [Hungarian]

[3] Wright, P. M., Hogan, N. S.: Grief theories and models. J. Hospice Palliat. Nurs., 2008, 10(6), 350-356.

[4] Kübler-Ross, E.: On death and dying. [A halál és a hozzá vezető út.] Gondolat Kiadó, Budapest, 1988. [Hungarian] 
[5] Pilling, J.: Mourning. [Gyász.] Medicina Könyvkiadó, Budapest, 2003. [Hungarian]

[6] Keegan, O.: Bereavement - a world of difference. In: Oloviere, D., Monroe, B., Payne, S. (eds.): Death dying and social differences. 2nd ed. Oxford University Press, 2011.

[7] Neimeyer, R. A.: Narrative strategies in grief therapy. J. Construct. Psychol., 1999, 12, 65-85.

[8] Stroebe, M., Schut, H.: The dual process model of coping with bereavement: rationale and description. Death Stud., 1999, 23(3), 197-224.

[9] Gillies, J., Neimeyer, R. A.: Loss, grief, and the search for significance toward a model of meaning reconstruction in bereavement. J. Construct. Psychol., 2006, 19, 31-65.

[10] Hogan, N. S., Schmidt, L. A.: Testing the grief to personal growth model using structural equation modeling. Death Stud., 2002, $26(8), 615-634$.

[11] Tedeschi, R. G., Calhoun, L. G.: Posttraumatic growth: Conceptual foundations and empirical evidence. Psychol. Inquiry, 2004, 15(1), 1-18.

[12] Stroebe, M., Schut, H.: The dual process model of coping with bereavement: a decade on. Omega (Westport), 2010, 61(4), 273-289.

[13] Stroebe, M., Schut, H.: The dual process model of coping with bereavement: Overview and update. Grief matters. Austr. J. Grief Bereavement, 2008, $11(1), 4-10$.

[14] Neimeyer, R. A., Prigerson, H. G., Davies, B.: Mourning and meaning. Am. Behav. Scientist, 2002, 46(2), 235-251.

[15] Neimeyer, R. A., Klass, D., Dennis, M. R.: A social constructionist account of grief: Loss and the narration of meaning. Death Stud., 2014, 38(8), 485-498

[16] Neimeyer, R. A., Burke, L. A., Mackay, M. M., et al.: Grief therapy and the reconstruction of meaning: from principles to practice. J. Contemp. Psychother., 2010, 40(2), 73-83.

[17] Neimeyer, R. A.: Meaning reconstruction and the experience of loss. American Psychological Association, Waschington, DC, 2002.

[18] Michael, C., Cooper, M.: Post-traumatic growth following bereavement: A systematic review of the literature. Counselling Psyc. Rev., 2013, 28(4), 18-33.

[19] Lehman, D. R., Wortman, C. B., Williams, A.: Long-term effects of losing a spouse or child in a motor vehicle crash. J. Pers. Soc. Psychol., 1987, 52(1), 218-231.
[20] McIntosh, D. N., Silver, R. C., Wortman, C. B.: Religion's role in adjustment to a negative life event: coping with the loss of a child. J. Pers. Soc. Psychol., 1993, 65(4), 812-821.

[21] Lichtenthal, W. G., Currier, J. M., Neimeyer, R. A., et al.: Sense and significance: a mixed methods examination of meaning making after the loss of one's child. J. Clin. Psychol., 2010, 66(7), 791-812.

[22] Calhoun, L. G., Tedeschi, R. G., Cann, A., et al.: Positive outcomes following bereavement: paths to posttraumatic growth. Psychol. Belgica, 2010, 50(1-2), 125-143.

[23] Tedeschi, R. G., Calboun, L. G.: The foundations of posttraumatic growth: New considerations. Psychol. Inquiry, 2004, 15(1), 93-102.

[24] Doka, K. J.: Disenfranchised grief: New directions, challenges, and strategies for practice. Research Press, Champaign, 2002.

[25] Lieberman, M. A.: Doors close, doors open: Widows, grieving, and growing. G. P. Putnam \& Sons, New York, 1996.

[26] Linley, P. A., Joseph, S.: Positive change following trauma and adversity: a review. J. Traumat. Stress, 2004, 17(1), 11-21.

[27] Milam, J. E., Ritt-Olson, A., Unger, J. B.: Posttraumatic growth among adolescents. J. Adolesc. Res., 2004, 19(2), 192-204.

[28] Helgeson, V. S., Reynolds, K. A., Tomich, P. L.: A meta-analytic review of benefit finding and growth. J. Consult. Clin. Psychol., 2006, 74(5), 797-816.

[29] Wolchik, S. A., Coxe, S., Tein, J. Y., et al.: Six-year longitudinal predictors of post-traumatic growth in parentally bereaved adolescents and young adults. Omega (Westport), 2008-2009, $58(2), 107-128$.

[30] Parkes, C. M.: Traditional models and theories of grief. Bereavement Care, 1998, 17(2), 21-23.

[31] Robánszky, M.: The psychosocial characteristics of the disease process. In.: Rohánszky, M., Kegye, A., Molnár, M., et al. (eds.): The psychosocial oncology. [A betegségfolyamat szakaszainak pszichoszociális sajátosságai. In: Rohánszky, M., Kegye, A., Molnár, M., et al. (szerk.): Pszichoszociális onkológia.] Zafír Press Könyvkiadó, Budapest, 2014. [Hungarian]

(Menyhért Mónika, Pécs, Rákóczi út 2., 7623 e-mail: menyhertmonikal2@gmail.com) 